\title{
The Development of Model Design Inclusive Education Learning
}

\author{
Hamsi Mansur ${ }^{*}$, Mohd Hanafi bin Mohd Yasin², Herita Warni ${ }^{3}$, Agus Hadi Utama ${ }^{4}$ \\ ${ }^{134}$ Faculty of Education, Lambung Mangkurat University (ULM), Indonesia \\ ${ }^{2}$ Faculty of Education, The National University of Malaysia (UKM), Malaysia
}

\begin{abstract}
The learning of inclusive education will run in accordance with the national education goals, characteristics, and culture of the Indonesian social system when applied in a clear and measured model of inclusive education learning. However, the learning process of inclusive education in Indonesia does not mean there are no challenges and failures, and so far, there has not been a model based on local wisdom. Therefore, the development of inclusive learning design models based on local wisdom becomes more important. This research aims to produce a product development model of inclusive education learning design based on local wisdom. This model was developed using a combination of the Borg \& Gall model that accommodates the local wisdom of inclusive education. Local wisdom in inclusive education is reflected in three characters, namely: respect for diversity, cooperation, and a sense of brotherhood. This research was conducted in 100 schools that provide inclusive education. The result is that the design of inclusive education learning must follow components such as: the process of identification and assessment of special needs, the curriculum is developed with a modification model, the availability of human resources (GPK), and assessment of learning processes for special needs students is arranged and adapted to the conditions/characteristics of students and system culture Indonesian social society. The implications of the findings above schools need to prepare human resources, infrastructure, funding allocation, and regulations set by schools in the implementation of inclusive education.
\end{abstract}

Keywords

Inclusive education learning; Inclusive education learning model design

Article Received: 20 September 2020, Revised: 30 November 2020, Accepted: 18 December 2020

\section{Introduction}

Inclusive education can be understood as recognition, appreciation for the existence and respect for diversity and diversity (Ministry of National Education: 2003). Thus, an inclusive society can be interpreted as a society that is capable of accepting various forms of diversity and diversity and accommodating them to the various structures of community life. As for what is meant by various forms of diversity and diversity including cultural diversity, language, gender, race, ethnicity, and economic strata, as well as including different physical / mental abilities, which we later call disability (Abdulrahman: 2003).

The principle of inclusive education has actually emerged in the Banjar community order. The spirit and values of unity in diversity, mutual cooperation, freedom, tolerance, and tolerance as grown and taught by the ancestors of the Banjar community can actually be interpreted as part of the principles that lead to a fundamental understanding of inclusive society (Directorate of SLB Development: 2009). Not only that, the fact that Indonesia is a large country that is multicultural, multi-religious and multi-diversity is actually a fertile medium for the growth and development of an inclusive society. Thus, it cannot be said that inclusive culture is a new value that is forced to enter and be adopted by the order of our society, it is precisely the values that have long been embedded in the social fabric of the Indonesian people that need to be maintained.

Inclusive education is a dynamic process, so that inclusive education continues to live, there needs to be continuous participatory monitoring, which involves all stakeholders in critical self-reflection. One core principle of inclusive education is that it must be responsive to diversity in a flexible, everchanging and unpredictable manner. Thus, inclusive education must remain alive and operate in accordance with the mandate of the constitution.

Each region has human resources, characteristics, and culture and a very basic and diverse social system. If these things can be used as considerations in implementing inclusive education, surely the implementation will run in accordance with the planned objectives of Education. These factors are not considered when 
the implementation of inclusive education is rolled out, causing the most fundamental problems in the implementation of inclusive education (Hanafi, Mohd \& Yasin, Mohd \& Jasmy, Mohd, et al., 2019). Previous research on the effectiveness of inclusive education shows that the implementation of inclusive education in the preparatory component (antecedents), the process component (transaction), and the product component (outcomes) have not been effective (Mansur, Hamsi, Yasin, Mohd \& Liong, K., 2019). Therefore, the design model of inclusive education learning based on local wisdom should meet the local wisdom components and be flexible.

Indonesia has long had the characteristics and culture of an inclusive education social system. Cultural mutual cooperation such as a sense of acceptance and giving opportunities to all children who have physical/mental disorders and or have special talents can learn together with children in general without discrimination. An inclusive learning design model based on local wisdom needs to be developed to be used as a reference in the learning process of inclusive education in Indonesia.

\section{Literature Review}

Various types of inclusive education learning strategies can affect the effectiveness of the inclusive learning process in accordance with the conditions/characteristics of special needs students (Lee, Lay Wah., 2010). Knowledge and attitudes of special needs students need to be identified first and assessed in the recruitment stage (Hasnah, Toran \& Muhamad, Tajul, et al., 2010). The implementation of inclusive education will be carried out properly and effectively if the recruitment system is carried out correctly, namely through the stages of identification and assessment of the conditions / characteristics of special needs students (Hanafi, Mohd \& Yasin, Mohd \& Jasmy, Mohd, et al., 2019). The ability of special assistant teachers (GPK) in identifying and assessing students with special need must have an exceptional educational background (Kamariah, Nur \& Mohd, Isa \& Hamzah, et al., 2019). The ability of GPK to assist students with special need is influenced by the desire and awareness of the inculcation of inclusive education (Anthony, Nancy \& Yasin, Mohd., 2019). The means and infrastructure of inclusive education has been widely implemented in the form of digitalization or learning media based on technology and information (Mohd Rashid, Syar \& Yasin, Mohd \& Ashaari, Noraidah., 2019).

The inclusive education evaluation model consists of three components, namely: preparation (antecedent), process (transaction), and product (Mansur, Hamsi, Yasin, Mohd \& Liong, K., 2019). The assessment of special needs students is aligned with the modification of the PPI curriculum, namely individual learning programs (Omar, Shokhan \& Yasin, Mohd \& Razak, et al., 2019). The assessment of special needs students is prioritized for changing attitudes and behavior in the surrounding environment (Omar, Shokhan \& Radzani, Mohd \& Yasin, et al., 2018). The assessment of special needs students is seen from the aspect of knowledge adjusted to the stage of development of the condition/characteristics of students (Abdulrahman, SO \& Razak, MRA \& Yasin, et al., 2018). Inclusive education in Indonesia for student with special need is very compatible with the social culture of the Indonesian people in the perspective of Islamic epistemology (Baharun, H., \& Awwaliyah, R., 2018).

Indonesian people have realized the importance of inclusive education learning because it is in accordance with the teachings of Islamic religion (Muqoyyidin, AW, 2013). The development of an inclusive school curriculum modification model based on the individual needs of students needs to be re-evaluated according to the conditions/characteristics of individuals and the culture of Indonesian social systems (Salim, A., 2010). The implementation of policies on the implementation of inclusive education in Indonesia needs to be re-evaluated based on a model of inclusive education learning design that is in accordance with the conditions/characteristics of individuals and the culture of Indonesian social systems (Sudarto, Z., 2016). But the attitude of teachers towards the implementation of inclusive programs in terms of the teacher itself is still very minimal in the 
insights of the design of inclusive education learning, one of the contributing factors is the lack of educators with special educational backgrounds to become special assistant teachers (GPK) in inclusive schools (Tri Wulandari, A., \& Pandia, WSS, 2015).

\section{Methodology}

This research is included in the category of Research and Development (R\&D). In this aspect, the research search for answers to research questions is also packaged in the formulation of the problem of creating an inclusive educational learning design model that is in line with national education objectives, characteristics, regional cultural diversity / wisdom local, and Indonesian people's social system culture. In this regard, the development of a model / design development is determined in its development. The model used to develop inclusive learning design models based on local wisdom is a combination of Borg \& Gall (1983) and Martin Tessmer (1996) so that the following development procedures are created: Analysis (Research \& Information collection), Design (Planning and Prototyping), Development and Formative Evaluation (Experts Review, One to One Evaluation, Small Group Evaluation, and Field Test), and Implementation (Dissemination and Implementation). For further research design can be illustrated in the chart below:

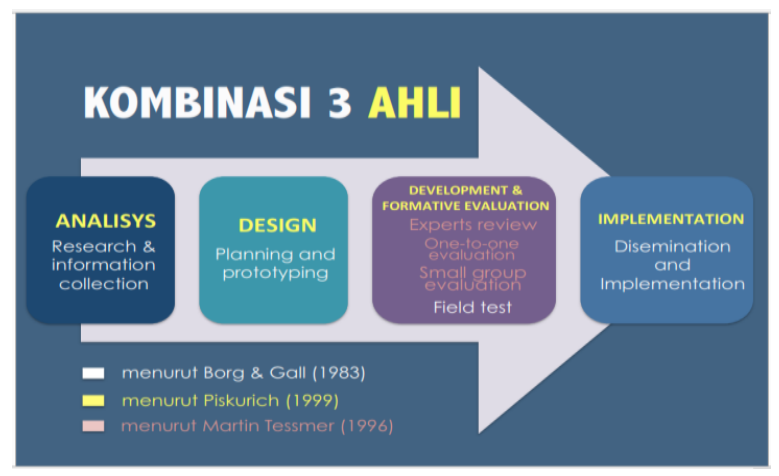

Figure 1. Model design development

Model Inclusive learning design model based on local wisdom validated by PLB UPI Bandung inclusive education experts and colleagues. Data collection techniques using observation and interview methods. Population and sample taken from 100 schools that provide inclusive education. After the data obtained through interview and observation methods were collected, the researchers conducted a qualitative descriptive data analysis.

The data analysis used is the analysis of the interactive model data of Miles, MB \& Huberman, AM, in Rohidi, TR, 1992 will be presented as follows:

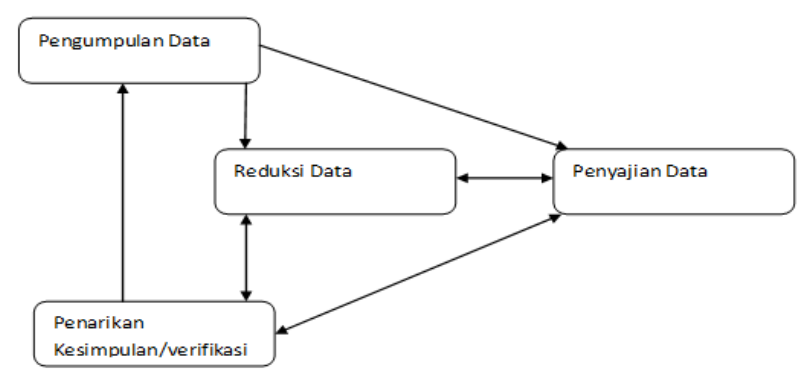

Figure 2. Model design analysis interactive

\section{Results and Discussion}

\section{Factual Conditions for the Implementation of Inclusive Education}

The results of the study indicate that the implementation of inclusive education are as follows: First, the principal's and teacher's knowledge of inclusive education is still very minimal. Second, there is no GPK for children with special needs. Third, teacher knowledge about the concept of inclusive education learning and knowledge of children with special needs is still minimal. Most teachers in inclusive schools have never participated in enrichment or training related to inclusive education. Only around 1-2 people from each school get the chance to join the training. The teacher representative is expected to transmit knowledge gained through training as well as seminars and workshops. However, this has not yet been realized optimally. In addition, seminars and workshops that have been given only touched the pedagogical side, but missed seeing the psychological side of the readiness of the participants (teachers).

Fourth, learning planning is carried out without consideration and identification. The lack of planning and assessment will certainly have an impact on the handling of special characteristics/conditions of students. Without doing an assessment, the teacher will not know the problems in students with special needs. This way 
of course they also will not be able to establish optimal inclusive education services. Moreover, children with special needs include a variety of types and varying degrees of abnormality. Assessment is the only way how and in what way the teacher can provide inclusive education services that are suitable for children with special needs. Thus, it will be easier to achieve an increase in student competence in the learning process.

Fifth, the acceptance of children with special needs $(\mathrm{ABK})$ in the school is still fairly "selective logging". Sixth, ABK has not been fully involved in the learning process. Seventh, learning systems that have not accommodated the learning needs of ABK. Eighth, the learning assessment system is likened to $A B K$ and children in general. Ninth, classroom and school environments that do not yet have standard facilities and infrastructure/accessibility for ABK. Tenth, the school committee has not yet maximized its role in supporting the implementation of inclusive education. Tenth, the school budget (funding) is still

\begin{tabular}{|c|c|c|c|}
\hline \multirow[b]{2}{*}{ No } & \multicolumn{3}{|c|}{ Factual Condition } \\
\hline & Indicators & $\begin{array}{l}\text { Data Collection } \\
\text { Instruments }\end{array}$ & Findings \\
\hline 1 & $\begin{array}{l}\text { Principal and Teacher Knowledge about } \\
\text { Providing Inclusive Education }\end{array}$ & $\begin{array}{l}\text { Observation \& } \\
\text { Interview }\end{array}$ & Minimal \\
\hline 2 & $\begin{array}{l}\text { Availability of GPK in Schools Providing } \\
\text { Inclusive Education }\end{array}$ & $\begin{array}{l}\text { Statistics on GPK } \\
100 \text { Schools } \\
\text { Providing Inclusive } \\
\text { Education }\end{array}$ & $\begin{array}{l}40 \% \text { Availability of GPK } \\
\text { in Inclusive Organizing } \\
\text { Schools }\end{array}$ \\
\hline 3 & $\begin{array}{l}\text { Teacher Knowledge about the Inclusive } \\
\text { Education Learning Process }\end{array}$ & $\begin{array}{l}\text { Observation \& } \\
\text { Interview }\end{array}$ & Minimal \\
\hline 4 & ABK Identification and Assessment & $\begin{array}{l}\text { Observation \& } \\
\text { Interview }\end{array}$ & Poorly planned \\
\hline 5 & ABK Recruitment System & $\begin{array}{l}\text { Observation \& } \\
\text { Interview }\end{array}$ & Selective Purpose \\
\hline 6 & Curriculum Modification Model & $\begin{array}{l}\text { Observation \& } \\
\text { Interview }\end{array}$ & Poorly planned \\
\hline 7 & Learning process & $\begin{array}{l}\text { Observation \& } \\
\text { Interview }\end{array}$ & $\begin{array}{l}\text { Lack of Media and } \\
\text { Learning Resources that } \\
\text { Acknowledge ABK }\end{array}$ \\
\hline 8 & ABK Assessment System & $\begin{array}{l}\text { Observation \& } \\
\text { Interview }\end{array}$ & $\begin{array}{l}\text { Lack of Media and } \\
\text { Learning Resources that } \\
\text { Acknowledge ABK }\end{array}$ \\
\hline 9 & Infrastructure & $\begin{array}{l}\text { Observation \& } \\
\text { Interview }\end{array}$ & $\begin{array}{lr}\text { Minimum } & \text { ABK } \\
\text { Accessibility Availability }\end{array}$ \\
\hline 10 & School Committee & $\begin{array}{l}\text { Observation \& } \\
\text { Interview }\end{array}$ & Lack of Budget Funds \\
\hline
\end{tabular}

\section{Designing Models for Inclusive Education Learning}

Planning for designing learning design models for children with special needs in schools providing education by:
- Analyzing the factual conditions of the implementation of inclusive education by formulating aspects of the strengths and weaknesses of schools in organizing inclusive education. To that end, so that these aspects can be formulated using SWOT analysis. This analysis is based on logic that can maximize strengths (Strengths) and opportunities (Opportunities), but simultaneously can 
minimize weaknesses (Weaknesses) and threats (Threats). The strategic decisionmaking process is always related to the development of vision, mission, goals, and strategic plans to produce appropriate design learning models of inclusive education. In addition, when the SWOT analysis is used to measure schools, it is possible for a school to get a comprehensive picture of the situation of the school in relation to the community, other educational institutions, and the resulting input-process-output. Whereas an understanding of external factors, (consisting of threats and opportunities), combined with an examination of strengths and weaknesses will help in developing a vision, mission, goals, and strategic plan about the design model of inclusive and relevant inclusive learning education. Forecast like this is applied by starting to create competent inclusive education programs or replacing irrelevant and excessive programs with programs that are more fragile, innovative and relevant.

- Analyzing Internal and External Factors. Several internal environments in schools providing inclusive education: 1) Educators and administrative staff; 2) Classes, laboratories, accessibility, facilities and infrastructure (learning environment); 3) Characteristics/conditions of existing $\mathrm{ABK}$ students; 4) Inclusive school operational budget; 5) Learning curricula, extra, intra and Co-curricular activities; 6) Organizational structure and school committees. Several external environments in the host school's Inclusive education: 1) Parents and families of students; 2) Structure of social systems/community environment; 3) Schools/institutions as preparation for continued; 4) regional cultural diversity/local wisdom; 5) Regional demographics and economic factors

From both environments, both internal and external environments must be managed properly. If not, then something that should be a strength will later turn into a weakness for the schools providing inclusive education. The connection with this research, is the internal and external environment for schools providing inclusive education as a potential reinforcer in the preparation of local wisdom-based learning design models are as follows: First, the internal environment has the potential to run a learning design model for children with special needs because the school committee, teaching staff, and administrative staff, as well as classrooms are able to be optimized. Second, the external environment. Students' parents and families are invited to participate in the organization of inclusive education. Participation and contributions from parents of students will be carried out well if some information regarding the school program is able to be well communicated (Abdulrahman, M., 2018).

\section{Development of an Inclusive Educational Learning Design Model}

Formulating a plan for a model of inclusive education learning design based on local wisdom based on theory and assisted by peers (PLB UPI Bandung) by Dr. Hidayat. The formulation of this model plan was then discussed in limited terms with a number of teaching staff in schools providing inclusive education. The draft formulation of inclusive wisdom learning design based on local wisdom is presented as follows:

- The identification and assessment. Identification and assessment process are carried out with due regard to the local wisdom of the Indonesian people, one of which is to respect diversity and not be selective in recruiting ABK. The identification/recruitment process is carried out once in a new school year. Because schools providing inclusive education have limited special assistant teachers (GPK), it is recommended to limit the registration of children with special needs. A minimum of 1 and or a maximum of 2 children with special needs in each class with the classification of the child can already control emotions and behavior in the classroom not based on weaknesses in their academic abilities. Selection is done by giving opportunities (quota) to all ABK who register and graduation is determined by the emotional and social level of children with special needs. 
In recruiting the special needs of the school, the specialists involve experts to measure the emotional and social level of the child. Children with special needs who have not yet been accepted at school are then recommended at other inclusive schools that have implemented inclusive education. ABK recruitment by involving experts is intended so that schools have students' personal data properly and accurately. Schools that do not have ABK personal data have an impact on the learning process and/or the development of ABK's talents and interests themselves. In addition, the school cannot promote ABK achievements or works. Thus, the availability of $\mathrm{ABK}$ personal data that is adequate at every $A B K$ recruitment starts the inclusive school policies on $\mathrm{ABK}$.

Learning planning for children with special needs begins through academic assessment and student development assessment. Assessment activities carried out by experts in collaboration with GPK. The results of the assessment activities become the main reference in planning learning or adjusting the curriculum for children with special needs (Berit H. Johnsen and Miriam D. Skjorten, 2003).

- The curriculum was developed with a modification model

The development of the modified model curriculum was carried out by taking into account the local wisdom of the Indonesian people, namely mutual cooperation, mutual cooperation, and help in carrying out learning activities in accordance with ABK conditions. The curriculum used in the inclusive class is a normal (regular) children's curriculum that is adjusted (modified according to) to the initial abilities and characteristics / conditions of special needs students. The curriculum development model is called the type of modification model. The curriculum component in the form of a modified learning aspect lies in the four main components of learning, namely syllabus, lesson plans, and evaluation systems. Next determine the preparation of the Individual Learning Program (PPI). The development of individual education programs is based on $\mathrm{ABK}$ personal data held by the school at the time of admission of special needs students. So, it is possible for inclusive schools that do not have ABK personal data not to make PPI. Without PPI, the program implemented is not in accordance with the talents and interests of ABK.

The learning process for children with special needs is to position children according to their social abilities. It is recommended that children with special needs sit on the edge of the classroom. Class teachers explain learning as usual, followed by GPK who continue to control the situation of children with special needs. After the subject teacher explains and provides assignments for students in general, then GPK guides children with special learning needs individually according to the PPI that has been prepared. If $\mathrm{ABK}$ is able to follow classical learning, GPK does not need to guide individually. When the learning process is expected that class teachers always use audiovisual media assisted by GPK to assist ABK in understanding learning material.

- The availability of human resources (GPK) availability of human resources is recruited from study programs or PLB majors who already have experience and a sense of brotherhood that reflects the local wisdom of the Indonesian people. A special assistant teacher (GPK) must have a high sense of brotherhood and affection in protecting ABK conditions. The role of the special assistant teacher (GPK) is indispensable in the achievement of the successful implementation of inclusive education programs. GPK is assisted by experts to conduct initial identification, academic assessment, and assessment of students' mental / social development. GPK which is incorporated in the school committee is also given an understanding by the school to support inclusive education programs both moral support and funding. Efforts to meet the availability of human resources (GPK) is to propose cooperation with the nearest SLB. The aim is to help assess children with special 
needs. In addition, schools can also work together in the provision of assistive devices for children with special needs.

- Assessment of learning processes for special needs students

The assessment of the learning process in inclusive education is evaluated on an ongoing basis in the sense of whether there are changes in attitudes and behavior between special needs students and regular students in paying attention to individual diversity, mutual assistance, please help, the emergence of affection, and a sense of brotherhood. Assessment of learning outcomes for children with special needs has been equated with other students. Class teacher's lack of understanding of the learning outcomes assessment system and the determination of class improvement for children with special needs causes the teacher to treat the same assessment as other students. The grading system that is commonly used in determining student grade inclusion in inclusive schools is based on the achievement of mental skills. Most children with special needs cannot go up to class because they do not meet the standard of mastery learning and grade promotion that has been determined.

In an inclusive education setting the systematic and ongoing assessment of learning outcomes aims to assess the learning outcomes of students in schools, take responsibility for organizing education to the community, and know the quality of education in schools. Continuous assessment means making continuous observations about something that is known, understood, and can be done by students. In inclusive education settings the school assessment system is expected to be flexible, especially for students with special needs.

The assessment system is tailored to the abilities of all children including children with special needs. Flexible assessment that can be applied through two models, namely the tasks for which the data are quantitative or qualitative (portfolio). In an effort to implement friendly learning for all children, assessment can be carried out by taking into account the conditions and differences of each individual. For this reason, at the end of the lesson the teacher tests for children with special needs to measure their ability to receive lessons. Assessment is done by adjusting the learning plan and or PPI. Of course, the value of the minimum completeness criteria (KKM) for $\mathrm{ABK}$ is also adjusted. It means, the score given to ABK is not different from students in general, for example vulnerable 10-100 with different learning completeness criteria with students in general. In addition to using tests, class teachers also assess student work in the form of portfolios.

Children with special needs also get the same report cards as children in general and are filled in accordance with the test results and the results of the learning process in the classroom. Children with special needs who have not been able to academically stay in the classroom are not advised to stay in class and again will be identified and academic assessment in the next learning plan. Children with special needs who are able to take part in academic activities such as students are generally registered to take part in the National Examination. However, children with special needs who have not been able to take the National Examination, it is sufficient to hold a school exam whose instrument is arranged by the subject teacher who has taught the ABK. Diplomas accepted by $\mathrm{ABK}$ and students are generally the same and not differentiated.

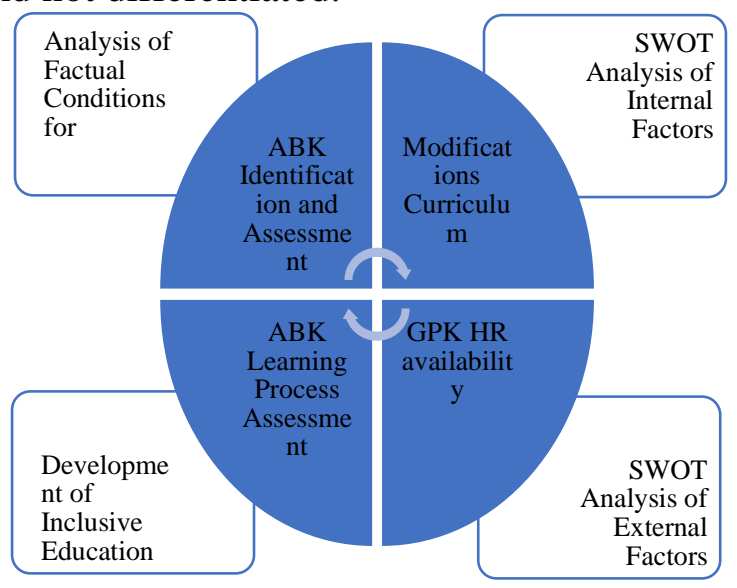

Figure 3. Model of Inclusive Education Learning Design

Conclusions and Recommendations 
The design model of inclusive education learning based on local wisdom can be used as a learning guide in inclusive schools. The components of the implementation of the design model are as follows:

- $\mathrm{ABK}$ identification and assessment process is carried out by experts and GPK.

- The curriculum was developed with a modification model at the level of the design of learning devices, especially individual learning programs (PPI).

- The availability of GPK HR can be done by collaborating with related partner institutions such as SLB.

- ABK special learning process assessment reports are prepared and adjusted to the conditions / characteristics of students.

Based on the inclusive learning design model that has been described, it is recommended that schools as implementers of inclusive education need to prepare human resources (special tutors), infrastructure that supports the implementation of the inclusive learning process, has adequate funding allocation so that the inclusive learning process runs effective, making standard guidelines for the implementation of inclusive learning with regulations set by the school. The regulations in question are: curriculum modification, preparation of individual learning programs (PPI), as well as assessment standards for students with special needs.

\section{References}

[1] Abdulrahman, M. (2018). Landasan Pendidikan Inklusif dan Implikasinya dalam Penyelenggaraan LPTK. Makalah disajikan dalam Pelatihan Penulisan Buku Ajar Bagi Dosen Jurusan PLB yang Diselenggarakan oleh Ditjen Dikti. Yokyakarta, 26 agustus 2002.

[2] Abdulrahman, S.O. \& Razak, M.R.A. \& Yasin, Mohd \& Dauwed, Mohammed. (2018). Validity and Reliability Questionnaire for Social, Environment and Self-Efficacy Related of Deaf Adolescents Physical Activity. Journal of Theoretical and Applied Information Technology. 96. 70417054.
[3] Anthony, Nancy \& Yasin, Mohd. (2019). Trainee Teachers Level of Willingness for Inclusive Education. Journal of ICSAR. 3. 79-83. 10.17977/um005v3i12019p079.

[4] Baharun, H., \& Awwaliyah, R. (2018). Pendidikan Inklusi Bagi Anak Berkebutuhan Khusus Dalam Perspektif Epistemologi Islam. MODELING: Jurnal Program Studi PGMI, 5(1), 57-71.

[5] Berit H. Johnsen dan Miriam D. Skjorten (2003). Pendidikan Kebutuhan KhususSebuah Pengantar, Program Pendidikan Pasca Sarjana Universitas Pendidikan Indonesia. Bandung.

[6] Borg, W.R. \& Gall, M.D. Gall. (1983). Educational Research: An Introduction, Fifth Edition. New York: Longman.

[7] Departemen Pendidikan Nasional (2003). Kebijakan pemerintah Dalam Pendidikan Inklusi, Jakarta.

[8] Direktorat Pembinaan SLB, (2009). Pedoman Khusus Penyelenggaraan Pendidikan Inklusif, Jakarta: Dapartemen Pendidikan Nasional.

[9] Hanafi, Mohd \& Yasin, Mohd \& Jasmy, Mohd \& Rahman, Abd \& Tahar, Mohd Mokhtar \& Norfirdhaus, Siti \& Ashaari, Mohammed. (2019). Implementation of Inclusive Education Program in Malaysia \& Indonesia for Hearing Impaired Students. International Journal of Emerging Technologies in Learning (iJET). 7. 16-19.

[10] Hasnah, Toran \& Muhamad, Tajul \& Yasin, Mohd \& Tahar, Mohd Mokhtar \& Hamzah, Nur. (2010). Knowledge and Attitude of Peers Towards Students with Disabilities in Malaysian Public Institute of Higher Education. ASEAN Journal of Teaching \& Learning in Higher Education.

[11] Kamariah, Nur \& Mohd, Isa \& Hamzah, \& Hanafi, Mohd \& Yasin, Mohd \& Tahar, Mohd Mokhtar \& Haron, Zolkepeli \& Jasmy, Mohd \& Rahman, Abdul \& Bari, 
Safani \& Anis, Mohd \& Razak, Abdul \& Samah, Amiruddin. (2019). Teacher's Ability in Identifying Pupils with Disablity in Classroom, Kapit, Sarawak.

[12] Lee, Lay Wah. (2010). Different Strategies for Embracing Inclusive Education: A Snap Shot of Individual Cases from Three Countries. International Journal of Special Education. 25. 98-109.

[13] Mansur, Hamsi, Yasin, Mohd \& Liong, K., (2019). Expectations and Challenges of Implementation Inclusive Education Program: A Case Study. Int. J. Adv. Res. 7(7). 373-379.

[14] Miles, M. B. \& Huberman, A. M. (Rohidi, T. R). (1992), Analisis Data Kualitatif. Jakarta: Universitas Indonesia.

[15] Mohd Rashid, Syar \& Yasin, Mohd \& Ashaari, Noraidah. (2019). Undergraduate Students of Special Education's Readiness towards the Use of Information and Technology (ICT) in Teaching and Learning the Sign Language. Creative Education. 10. 2374-2385. 10.4236/ce.2019.1011169.

[16] Muqoyyidin, A. W. (2013). Membangun Kesadaran Inklusif Multikultural untuk Deradikalisasi Pendidikan Islam. Jurnal Pendidikan Islam, 2(1), 131-151.

[17] Omar, Shokhan \& Radzani, Mohd \& Yasin, Mohd \& Dauwed, Mohammed. (2018). Validity and Reliability Questionnaire for Social, Environment and Self-Efficacy Related of Deaf Adolescents Physical Activity. Journal of Theoretical and Applied Information Technology. 96.

[18] Omar, Shokhan \& Yasin, Mohd \& Razak, Mohd \& Dauwed, Mohammed. (2019). Physical Activity Measurement for Hearing Impairments in Different Age Level. 8. 2935.

[19] Salim, A. (2010). Pengembangan Model Modifikasi Kurikulum Sekolah Inklusif Berbasis Kebutuhan Individu Peserta Didik.
Jurnal Pendidikan dan Kebudayaan, 16(7), 21-34.

[20] Sudarto, Z. (2016). Implementasi kebijakan penyelenggaraan pendidikan inklusif. Jurnal Pendidikan (Teori dan Praktik), 1(1), 97106.

[21] Tessmer, Martin. (1996). Planning and Conducting Formative Evaluation; Improving the Quality of Education and Training. Faculty of Educational Science and Technology, University of Twente, London.

[22] Triwulandari, A., \& Pandia, W. S. S. (2015). Sikap guru terhadap penerapan program inklusif ditinjau dari aspek guru. JPPM (Jurnal Pendidikan dan Pemberdayaan Masyarakat), 2(2), 122-130. 